\title{
What motivates hunters to target exotic or endemic species on the island of São Tomé, Gulf of Guinea?
}

\author{
Mariana Carvalho, Jorge M. Palmeirim, Francisco C. Rego, Nelson Sole \\ Aristides SANTANA and Julia E. FA
}

\begin{abstract}
Hunting and invasive species are amongst the main causes of species extinctions on oceanic islands. On the island of São Tomé hunting of introduced mammals (monkeys, civets and pigs) and endemic bird species has contrasting effects in terms of conservation. Hunting of introduced mammals may benefit native fauna and flora but pressure on endemic birds poses a threat to some species. We conducted semi-structured interviews with 119 hunters to assess the relative importance of native and introduced prey species, gathering information on personal profiles, preference and practice, and hunters' perceptions of trends in prey populations. Eleven species were hunted, including five invasive mammals and five endemic birds of high conservation importance. Based on species hunted, techniques used and final destination of the quarry we distinguished three groups of hunters, using cluster analyses: bird, monkey and feral-pig hunters. Bird hunters were all from urban areas but most pig hunters were rural. Monkey hunters were mostly rural workers but a small proportion were from urban areas. Bird and monkey hunters were primarily motivated by commercial gains but they also hunted for enjoyment and food. In general, hunting of mammals is an opportunistic activity that, if regulated, can be sustainable and contribute to mitigating the effects of invasive species on local fauna as well contributing to local livelihoods. Given the economic drivers involved in hunting of birds, intervention to reduce or eliminate this form of hunting will require enforcement of legislation and raising awareness of the issues involved.
\end{abstract}

Keywords Endemic birds, Gulf of Guinea, hunter behaviour, invasive mammals, islands, São Tomé, semi-structured interview

This paper contains supplementary material that can be found online at http://journals.cambridge.org

Mariana Carvalho (Corresponding author) and Francisco C. Rego Centro de Ecologia Aplicada 'Prof. Baeta Neves', Instituto Superior de Agronomia, Tapada da Ajuda, 1349-017 Lisbon, Portugal. E-mail marianafruitdove@gmail.com

Jorge M. Palmeirim Dept. Biologia Animal/Centro de Biologia Ambiental, Faculdade de Ciências, Universidade de Lisboa, Lisbon, Portugal

Nelson Sole and Aristides Santana Associação Monte Pico, Monte Café, São Tomé, Democratic Republic of São Tomé and Príncipe

Julia E. FA Durrell Wildlife Conservation Trust, Les Augrés Manor, Trinity, Jersey, and ICCS, Imperial College London, Division of Biology, Silwood Park Campus, Ascot, UK

Received 21 November 2012. Revision requested 7 January 2013. Accepted 14 March 2013. First published online 24 February 2014.

\section{Introduction}

T umans have affected island ecosystems through - L habitat modification, hunting and the introduction of domesticated and feral animal species (Kirch, 1997; Didham et al., 2005a,b). Rabbits, goats, pigs and cattle have commonly been introduced to islands but wild mammals have also been deliberately released in some cases (Glenn \& Cords, 2002). Human-introduced animals such as rats, mice, cats and dogs have caused the extinction of many endemic species on oceanic islands (Duncan et al., 2002; Steadman, 2006).

Oceanic islands in the Gulf of Guinea, off the west coast of Africa, have been subject to centuries of habitat alteration and the effects of introduced species (Hodges \& Newitt, 1988). Collar and Stuart (1988) ranked the forests in southwest and central São Tomé second in a list of 75 of the most important forests for the conservation of threatened birds in Africa, based on the number of restricted-range bird species that occur there (Bibby et al., 1992; Jones, 1994; Stattersfield et al., 1998; Buchanan et al., 2011). The island has 17 endemic bird species, including two endemic monospecific genera, and endemic subspecies; most are forest-dwellers (BirdLife International, 2012).

Habitat modification is considered the most significant threat to the island's endemic birds but most taxa are also potentially threatened by non-native mammal species and by uncontrolled hunting. Bird hunting has been mentioned in the literature since the first naturalists' expeditions took place (Snow, 1950; de Naurois, 1983; Jones \& Tye, 1988; Atkinson et al., 1991; Peet \& Atkinson, 1994) but its effect is still poorly understood (Dallimer et al., 2009; de Lima et al., 2013). The species most at risk from any increase in hunting pressure are the endemic pigeons, such as the maroon pigeon Columba thomensis, the São Tomé bronzenaped pigeon Columba malherbii and the São Tomé green pigeon Treron sanctithomae, and the Critically Endangered dwarf olive ibis Bostrychia bocagei (IUCN, 2012).

Mammals such as African civets Civettictis civetta, mona monkeys Cercopithecus mona and feral pigs Sus scrofa were introduced to São Tomé in the 17 th century and are common throughout the island's forested habitats (Dutton, 1994; Glenn \& Bensen, 1996; Oliveira, 2002). Feral pigs are known to modify habitats by reducing the abundance of native plant species, increasing the establishment of invasive non-indigenous plants and indirectly affecting bird species in native forests (Nogueira-Filho et al., 2009). Pigs also cause watershed degradation by increasing soil erosion through 
foraging and travelling. Monkeys introduced to islands may not affect habitats directly but can become significant predators of endemic birds, particularly of their nests (Nowak, 1991; Furuichi, 2006). They also compete with frugivorous birds for food resources (Walker, 2007). Pigs and monkeys are recognized worldwide as destructive invasive species (Gurevitch \& Padilla, 2004; Cruz et al., 2005; Nogueira et al., 2007) and are known as a potential threat to endemic birds in São Tomé (Dutton, 1994).

Introduced mammals are among the most hunted quarry on São Tomé. Hunting of these exotic species can, in some circumstances, deflect attention from native species (Desbiez et al., 2011). However, the hunting of endemic birds, either opportunistically or for commercial purposes, can threaten their survival because tropical island forest birds generally have reduced fecundity, longer developmental periods and increased investments in young than their mainland counterparts (Covas, 2012). Such reproductive traits are likely to render island birds more sensitive to increased adult mortality as a result of hunting, as shown for Holocene bird extinctions in New Zealand (Duncan et al., 2002).

Hunting of wildlife for food or financial gain is often an essential activity that supports the livelihoods of the poor in many parts of the world (Bowen-Jones et al., 2003; Bennett et al., 2007). However, overexploitation of wild species is a main driver of defaunation of tropical forest ecosystems. Thus, understanding what motivates people to hunt wild animals is a critical first step to identifying reasons for unsustainable practices, threats and opportunities in conservation, and intervention options (Pailler et al., 2009). We investigated (1) the relative importance of native and introduced prey species to hunters on the island, (2) the motivation, preference and practice of hunters dedicated to hunting endemic birds and introduced mammals, and (3) hunters' perceptions of population trends of hunted prey and barriers to sustainability. Here we juxtapose two hunting systems that have contrasting effects on native wildlife. Based on our results we recommend measures to encourage hunting of introduced mammals and reduce hunting pressure on endemic birds.

\section{Study area}

São Tomé $\left(857 \mathrm{~km}^{2}\right)$ is the larger of the two oceanic islands that constitute the Democratic Republic of São Tomé and Príncipe (Fig. 1) and is located c. $200 \mathrm{~km}$ from the African coast. Annual rainfall ranges from $<1,000 \mathrm{~mm}$ in the north-east to $>7,000 \mathrm{~mm}$ in the south-west. Mean annual temperatures vary between $18-21^{\circ} \mathrm{C}$ and $30-33{ }^{\circ} \mathrm{C}$, with little seasonal variation and high humidity all year (Carvalho et al., 2004). The island is characterized by rough relief, with numerous steep mountains and a maximum altitude of $2,024 \mathrm{~m}$.
There was no permanent human settlement on the island before the Portuguese arrived in 1470 and the native vegetation comprised old-growth forest in the lowland areas $(<800 \mathrm{~m})$ and montane and mist forests on the higher and wetter side of the island (Jones \& Tye, 2006). Mist forest is still found at the highest altitudes but only a few patches of old-growth forest remain on the steeper and inaccessible slopes. Although lowland forests were modified to plant cocoa and coffee, the collapse in the economic value of these crops since the 1930 s has resulted in significant regeneration of secondary forest (Oliveira, 2002; Carvalho et al., 2004). The drier forest type on the north-east of the island (as a result of a rain shadow) has been cleared for farmland and estates and replaced by savannah and agroforestry (Carvalho et al., 2004).

Almost one-third of the island's land area has been designated a protected area, the Parque Natural do Obô (Albuquerque \& Cesarini, 2009), which includes most of the remaining old-growth forest and large areas of secondary forest, but there is little enforcement. Legislation on hunting has been in preparation since 1995. It was reviewed in 2012 but has yet to be promulgated. According to the proposal hunting of endemic bird species should be densityregulated, as is the case for the São Tomé green pigeon and the bronze-naped pigeon (and hunting should be totally restricted during known breeding periods). It is also proposed that hunting of internationally recognized threatened species, namely the maroon pigeon and the dwarf olive ibis, should be forbidden.

The human population is estimated at c. 187,000 (c. 212 inhabitants per $\mathrm{km}^{2}$; INESTP, 2012) and the growth rate is $2 \%$ (CIA, 2012). Approximately $60 \%$ of the inhabitants of the island live in or adjacent to the capital, São Tomé (INESTP, 2012). Poverty levels are high (34.5\%; Alkire et al., 2011) and infrastructure is generally poor.

\section{Methods}

\section{Interviews}

We used 12 key informants (former or current hunters, restaurant owners or managers and members of local civil associations) and a snowball approach to identify hunters operating on the island (Bernard, 2006). We checked the list regularly with these informants, generally during interviews with hunters, until no new names were mentioned. We identified 196 resident and active hunters on the island, of which we were able to interview 119 (61\%). The remaining hunters $(n=77)$ were removed from the sample because of the difficulty in meeting them or their reluctance to be interviewed. Of the excluded group, 20 were sport hunters; these were medium- to high-income earners (13 São Tomean and seven long-term expatriate residents). All sport hunters 


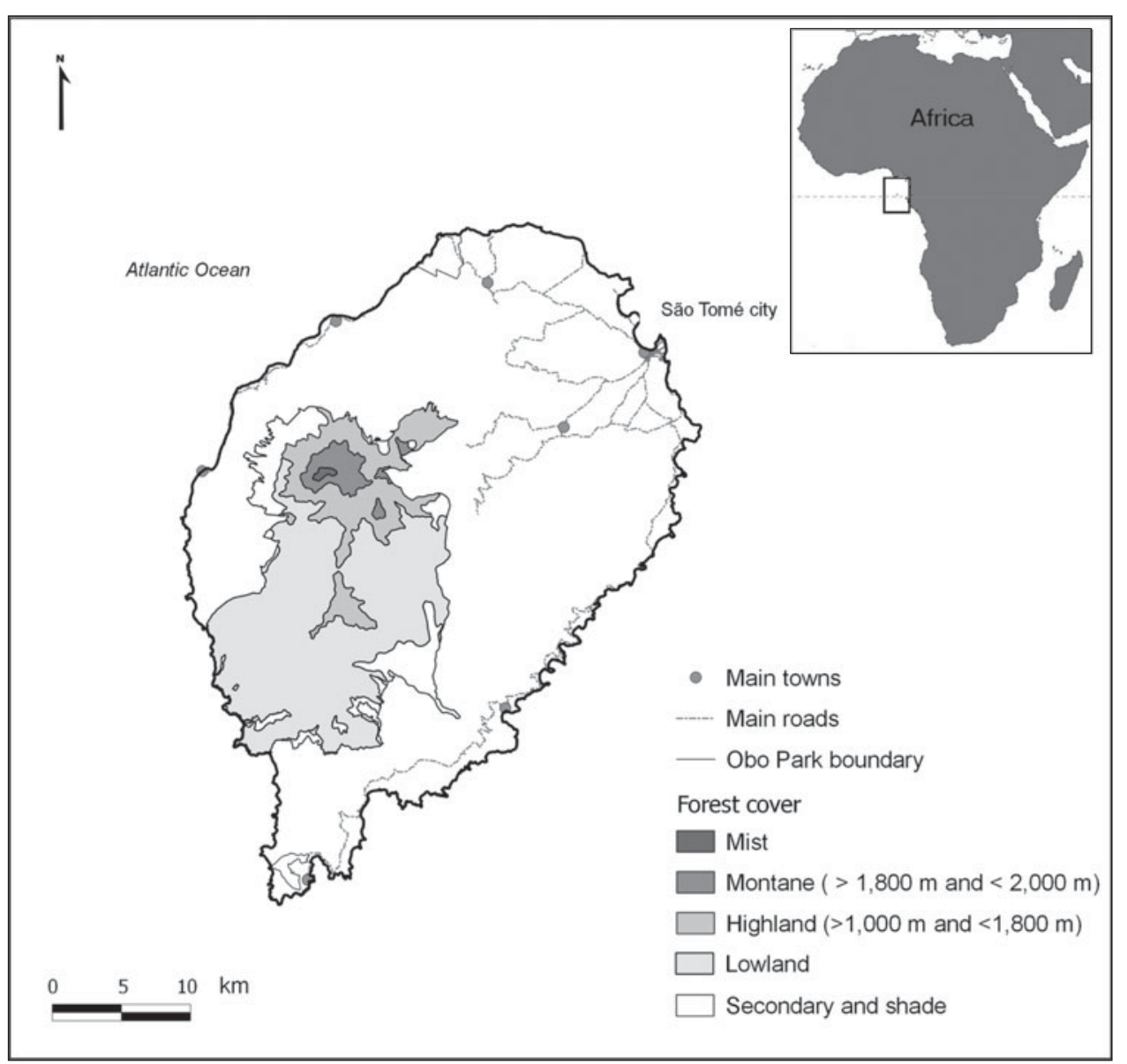

FIG. 1 Distribution of forest cover on the island of São Tomé. The rectangle on the inset shows the location of the island off the west coast of Africa. lived in the main city of São Tomé or in surrounding areas and hunted occasionally, in groups, for enjoyment.

We conducted all interviews during June 2008December 2010 in the homes of the selected hunters. We administered a questionnaire of 17 questions, mostly open-ended, taking care not to influence the responses (Supplementary Material 1). To verify the truthfulness of answers provided by respondents we included several questions that could be used to triangulate with other data sources and observations. Participation was voluntary: all hunters agreed to be interviewed beforehand and no incentives were offered. The length of the interview was such that sufficient time was available for interviewees to answer all questions asked, without attention drop-off.

The aim of the applied questionnaire was to gauge the socio-economic situation and current livelihood activities of the respondents as a means of determining whether socioeconomic status affected hunting motivation. We first asked interviewees which wildlife group (mammal, birds or no preference) or species they preferred hunting. We asked about the methods they used most commonly (e.g. shotguns, air guns, spears, dogs, snares or traps) and their main reason for hunting. We asked if the animals they hunted were for their own consumption, for sale, or both. If they hunted to sell we asked to whom they sold their quarry. To gauge whether hunting was full-time or subsidiary work we enquired about each hunter's main source of livelihood. We also asked the question 'Why do you hunt?' to allow interviewees to express their own views. Finally, we asked the hunters for their opinions about general trends in prey abundance in the previous decade and which species they considered to be less abundant at present.

\section{Data analyses}

All statistical analyses were performed using SPSS v. 20 (IBM, 2011). To understand the relative significance of the different prey species to São Tomé hunters we estimated a hunting importance value $(H v)$ for each of the species mentioned in their responses (adapted from Fernandes-Ferreira et al., 2012 and Phillips et al., 1994). For the question 'What animals do you hunt?' we did not define a minimum or maximum number of answers; the number varied between respondents from one to eight species (each species could only be mentioned once). The resulting value was based on the number of times each species was named relative to the 
TABLE 1 The prey species on the island of São Tomé (Fig. 1) that were mentioned by hunters in interviews, with hunting importance and preference values (see text for details of calculations) and IUCN Red List category (IUCN, 2012).

\begin{tabular}{|c|c|c|c|}
\hline Species & Hunting importance value $(H v)$ & Preference value $(P v)$ & IUCN Red List category $^{1}$ \\
\hline \multicolumn{4}{|l|}{ Mammals } \\
\hline Feral pig Sus scrofa ${ }^{2}$ & 22.02 & 47.01 & LC \\
\hline Mona monkey Cercopithecus mona ${ }^{2}$ & 24.40 & 35.99 & LC \\
\hline Fruit bat Eidolon helvum ${ }^{3}$ & 15.17 & 7.35 & LC \\
\hline Civet Civettictis civetta ${ }^{2}$ & 14.88 & 8.82 & LC \\
\hline Feral cat Felis catus ${ }^{2}$ & 2.38 & 0 & LC \\
\hline \multicolumn{4}{|l|}{ Birds } \\
\hline São Tomé green pigeon Treron sanctithomae 4 & 13.09 & 8.82 & VU \\
\hline Maroon pigeon Columba thomensis ${ }^{4}$ & 11.90 & 3.67 & EN \\
\hline Bronze-naped pigeon Columba malherbii ${ }^{4}$ & 11.31 & 4.41 & NT \\
\hline Helmeted guinea fowl Numida meleagris ${ }^{2}$ & 2.68 & 0 & LC \\
\hline Dwarf olive ibis Bostrychia bocagei ${ }^{4}$ & 0.60 & 0 & CR \\
\hline Small passerine birds ${ }^{2,3,4}$ & 0.60 & 0 & \\
\hline
\end{tabular}

${ }^{1}$ LC, Least Concern; VU, Vulnerable; EN, Endangered; NT, Near Threatened; CR, Critically Endangered

${ }^{2}$ Introduced

${ }^{3}$ Native

${ }^{4}$ Endemic

total number of citations of prey species for all interviewed hunters.

$$
H v=\sum\left(\frac{H s p}{\mathrm{n}}\right) * \mathrm{~N}
$$

where Hsp is the number of times a species is mentioned as a targeted animal, $\mathrm{n}$ is the total number of citations for all species (400) and $\mathrm{N}$ is the number of interviewees (119).

We also estimated a preference value $(P v)$ based on hunters' preferred species (excluding zero values; i.e. no preference). Hunters cited 1-3 preferred species.

$$
P v=\sum\left(\frac{P s p}{\mathrm{n}}\right) * \mathrm{~N}
$$

where $P s p$ is the frequency that each species is cited as a preferred species, $\mathrm{n}$ is the total number of citations for all prey species (158) and $\mathrm{N}$ is the number of interviewees (119).

Subsequently we described the interviewed hunters (three were excluded because of missing data) according to a set of numerical (age, literacy, number of years dedicated to hunting) and categorical variables (urban or rural origin, hunting as the main activity, other professional activities, methods and gear used to hunt, transport used, reasons for hunting). We used a cluster analysis to group hunters, based on factors with the highest inertia (Punj \& Stewart, 1983; Ketchen \& Shook, 1996; Bernard, 2006). As a first approach to the classification we recorded the categorical variables as dichotomous, assigning equal weights to all components. We then conducted a hierarchical cluster analysis, using Ward's linkage method with Euclidean distances to identify relatedness among hunters (Ward, 1963), from which we produced a dendrogram as our preliminary cluster solution.

Following the recommendation of Punj \& Stewart (1983) on combined analysis we used an iterative partitioning algorithm, using the centroids of the preliminary analysis as starting points. We employed a two-step cluster analysis with no cluster limits, using Schwartz Bayesian criteria to assess the importance of each variable to explain the characteristics of hunter groups, as defined by the hierarchical cluster analysis (Ketchen \& Shook, 1996). We then tested the variance between the resulting groups, using a one-way ANOVA for continuous variables and a Pearson $\chi^{2}$ test for categorical dichotomous variables.

\section{Results}

\section{Prey species}

The mean duration of interviews was 26 minutes (range 18-39 minutes). A total of six mammals and five bird species were specifically mentioned by the interviewees (Table 1). Fruit bats Eidolon helvum were the only native mammals mentioned. All bird species mentioned except the helmeted guinea fowl Numida meleagris are endemic and categorized on the IUCN Red List of Threatened Species (Table 1). Reported hunting values and prey preference (as shown by preference values) were highest for mona monkeys and feral pigs and lowest for guinea fowl, feral cats Felis catus, ibis and small passerine birds. Hunting and preference values for endemic pigeons were similar to those for fruit bats and civets but lower than for pigs and monkeys. 


\section{Hunter groups}

We identified three homogeneous groups through cluster analysis: group A (11.2\% of all hunters) and groups B and C ( $88.8 \%$ of all hunters). Results of the two-step cluster analysis indicated significant differences in the characteristics of the three groups (Table 2).

Group A primarily hunted birds, mostly targeting pigeons (92.3\%), although some also hunted fruit bats $(53.8 \%)$ and mona monkeys (30.8\%). No feral pigs were hunted by this group. Groups B and C, comprising 50 and $38.8 \%$ of all interviewed hunters, respectively, were characterized by a clear preference for hunting mammals rather than birds. Most group B hunters stated that they hunted monkeys (98.3\%), whereas Group C hunters focused on feral pigs (95.6\%). A lower proportion of Group B hunters (12.1\%) had no prey preference but $1.7 \%$ mentioned at least one bird species as preferred prey.

All bird hunters used air guns, with $61.5 \%$ also using shotguns. Pig hunters never used air guns and only $64.4 \%$ had shotguns; a large proportion commonly hunted with spears (68.9\%), dogs (84.4\%) and/or snares (22.8\%). Monkey hunters predominantly used shotguns (96.6\%), although some also used air guns (20.7\%) and/or dogs (25.0\%).

Bird hunters were all residents of urban or peri-urban areas, in and adjacent to São Tomé. Most (76.9\%) hunted frequently (2-5 times per week), with $46.2 \%$ declaring hunting as their main source of livelihood. Monkey hunters lived in rural as well as urban settings, practising hunting as a secondary activity 1-4 times per month (48.3\%), using public transport $(37.6 \%)$ or rented motorbikes $(12.2 \%)$ to get to an appropriate access point in the forest from which they continued on foot. Most pig hunters $(86.7 \%)$ were farmers or palm wine producers $(75 \%)$. This group hunted $2-5$ times per week $(62.2 \%)$, often during breaks from agricultural activities; most walked to the forest (97.8\%).

Bird hunters had significantly higher literacy levels than the other two groups $(53.8 \%$ had completed at least the 9 th school grade). The standard of literacy was generally low among pig hunters but higher amongst monkey hunters (most had completed the 7 th grade). The latter also worked at other activities besides hunting (46.2\% were employed in the service industry). Pig hunters were the youngest (mean age 29.5 years) and monkey hunters the oldest (mean age 35.7 years) amongst the three groups.

\section{Hunting drivers and motivations}

Bird hunters predominantly hunted to sell their quarry (84.6\%, of which $76.9 \%$ sold their game to restaurants or traders), with $<25 \%$ claiming to hunt exclusively for food (Table 2). Most monkey hunters also hunted for commercial gain $(82.8 \%)$, with $60.3 \%$ selling their quarry to restaurants or traders. Pig hunters hunted primarily for food, either for their own consumption or for sale $(48.9 \%)$ to neighbours or local residents (Table 2). A large proportion of hunters in the three groups stated that they hunted because they enjoyed it (Fig. 2). Only amongst bird hunters was survival mentioned as a major reason for hunting, paired with enjoyment. Few respondents stated that hunting was necessary to feed their families or to supplement their income. This suggests that the commercial demand for birds plays an important role in the household economy of bird hunters. Hunting of mammals, for food or for commercial reasons, is largely motivated by enjoyment, suggesting that hunters are less dependent on mammals as a source of protein or income.

\section{Hunters' perceptions}

Most hunters interviewed (81.5\%) claimed that there were fewer animals than a decade ago, $1.7 \%$ suggested that there were more and $16.8 \%$ did not know. The main reason given by $68.1 \%$ of interviewees was the rise in the number of hunters. A smaller percentage attributed the decline to habitat degradation (7.5\%). Of the bird hunters $42.8 \%$ mentioned that all prey species had declined but in particular maroon and green pigeons (Fig. 3). Circa 30\% of pig hunters stated there had been a fall in numbers of feral pigs and civets. A lower proportion of monkey hunters (15.5\%) indicated that monkeys had declined. Monkey hunters (27.6\%) also confirmed a drop in pig numbers.

\section{Discussion}

Hunting of introduced species can have a positive outcome for wildlife conservation, as described for feral pigs in the Brazilian Pantanal (Desbiez et al., 2011). However, situations in which hunting of introduced biota and native wildlife cooccurs are little known. We have shown that on São Tomé there are three groups of hunters, each targeting a distinct assemblage of prey species, although there is some overlap. The groups differ in age, educational background and socioeconomic status. In particular, the mean age of each group reflects the physical requirements of each type of hunting, e.g. pig hunting demands more active pursuit of prey by the hunter and therefore it is often carried out by younger men. In contrast, hunting of monkeys and birds is less demanding and this is reflected in the older mean ages of these two hunter groups.

Hunting of endemic birds, specifically pigeons, is of concern for the conservation of the island's unique biodiversity. Bird hunters are known to be effective in taking large numbers of birds during a hunting session as they are able to predict where birds are likely to congregate (e.g. around fruiting trees). The island's birds are relatively tame and therefore easy to shoot at close range. The amount of 
TABLE 2 Profiles of hunters' groups (derived from cluster analysis; see text for details) on the island of São Tomé (Fig. 1). A two-step cluster predictor value between o (less important) and 1 (maximum input for clustering) is provided for each variable. For continuous variables the mean value for each group and the ANOVA results for the variance between the three groups are presented. For categorical variables the percentage of hunters in each group and the Pearson $\chi^{2}$ for the frequency distribution amongst the three groups are presented.

\begin{tabular}{|c|c|c|c|c|c|c|}
\hline \multirow[b]{2}{*}{ Variables } & \multirow{2}{*}{$\begin{array}{l}\text { Predictor } \\
\text { importance } \\
(0-1)\end{array}$} & \multicolumn{3}{|c|}{ Hunter groups } & \multirow[b]{2}{*}{$\begin{array}{l}\text { Variability } \\
\text { between groups }\end{array}$} & \multirow[b]{2}{*}{ Significance } \\
\hline & & $\begin{array}{l}\text { A (birds; } \\
\mathrm{n}=13)\end{array}$ & $\begin{array}{l}\text { B (monkeys; } \\
\mathrm{n}=58)\end{array}$ & $\begin{array}{l}\mathrm{C} \text { (pigs; } \\
\mathrm{n}=45)\end{array}$ & & \\
\hline Continuous & & Mean \pm SE & & & ANOVA F & $\mathrm{P}$ \\
\hline \multicolumn{7}{|l|}{ Personal characteristics } \\
\hline Age & 0 & $31.3 \pm 2.9$ & $35.71 \pm 1.2$ & $29.5 \pm 1.4$ & 5.60 & 0.005 \\
\hline No. of dependents & 0.02 & $1.85 \pm 0.5$ & $3.86 \pm 0.4$ & $4.24 \pm 2.2$ & 14.88 & 0.001 \\
\hline Literacy level & 0.221 & $8.62 \pm 0.7$ & $6.52 \pm 0.3$ & $4.9 \pm 0.2$ & 21.73 & $<0.001$ \\
\hline Dichotomous & & $\%$ hunters & & & Pearson $\chi^{2}$ & $\mathrm{P}$ \\
\hline \multicolumn{7}{|l|}{ Personal characteristics } \\
\hline Lives in rural setting & 0.31 & 0 & 62.1 & 86.7 & 33.49 & $<0.001$ \\
\hline Lives in urban setting & 0.31 & 100 & 37.9 & 13.3 & 33.49 & $<0.001$ \\
\hline \multicolumn{7}{|l|}{ Main source of livelihood } \\
\hline Hunting & 0.11 & 46.2 & 8.6 & 15.6 & 11.41 & 0.003 \\
\hline Primary sector-farming & 0.24 & 0 & 67.2 & 75.6 & 25.61 & $<0.001$ \\
\hline Secondary sector-industry & 0.04 & 0 & 13.8 & 4.4 & 4.19 & 0.123 \\
\hline Tertiary sector-services & 0.23 & 100 & 31.0 & 26.7 & 25.01 & $<0.001$ \\
\hline \multicolumn{7}{|l|}{ Prey preference } \\
\hline Prefer mammals & 0.53 & 15.4 & 87.9 & 100 & 56.14 & $<0.001$ \\
\hline Prefer birds & 1.00 & 100 & 1.7 & 0 & 106.74 & $<0.001$ \\
\hline No preference & 0.07 & 0 & 12.1 & 0 & 7.45 & 0.24 \\
\hline \multicolumn{7}{|l|}{ Species hunted } \\
\hline Feral pig & 0.42 & 0 & 53.4 & 95.6 & 45.25 & $<0.001$ \\
\hline Mona monkey & 0.46 & 30.8 & 98.3 & 40 & 49.01 & $<0.001$ \\
\hline Civet & 0.04 & 30.8 & 39.7 & 57.8 & 4.67 & 0.97 \\
\hline Fruit bat & 0.18 & 53.8 & 60.3 & 17.8 & 19.41 & $<0.001$ \\
\hline Maroon pigeon & 0.37 & 92.3 & 34.5 & 4.4 & 39.08 & $<0.001$ \\
\hline São Tome green pigeon & 0.29 & 92.3 & 43.1 & 11.1 & 31.18 & $<0.001$ \\
\hline Bronze-naped pigeon & 0.34 & 92.3 & 39.7 & 6.7 & 36.09 & $<0.001$ \\
\hline Guinea fowl & 0.06 & 15.4 & 12.1 & 0 & 6.35 & 0.42 \\
\hline Other birds & 0.03 & 7.7 & 1.7 & 0 & 3.52 & 0.172 \\
\hline \multicolumn{7}{|l|}{ Hunting methods } \\
\hline Shotgun & 0.18 & 61.5 & 98.6 & 64.4 & 19.63 & $<0.001$ \\
\hline Air gun & 0.56 & 100 & 20.7 & 0 & 59.71 & $<0.001$ \\
\hline Spear & 0.46 & 0 & 8.6 & 68.9 & 49.59 & $<0.001$ \\
\hline Dog & 0.43 & 0 & 27.6 & 84.4 & 45.68 & $<0.001$ \\
\hline Snare & 0.07 & 0 & 6.9 & 22.2 & 7.62 & 0.022 \\
\hline Trap & 0.13 & 0 & 6.9 & 31.1 & 14.02 & 0.001 \\
\hline \multicolumn{7}{|l|}{ Reasons for hunting } \\
\hline Food & 0.22 & 49.0 & 15.4 & 17.25 & 13.62 & 0.001 \\
\hline Sale & 0.13 & 2.22 & 46.16 & 6.90 & 23.58 & $<0.001$ \\
\hline Both food and sale & 0.13 & 48.8 & 38.46 & 75.86 & 10.95 & 0.004 \\
\hline Sale to local communities \& neighbours & 0.04 & 27.6 & 7.7 & 37.8 & 4.57 & 0.102 \\
\hline Sale to restaurants \& traders & 0.25 & 60.3 & 76.9 & 15.6 & 26.65 & $<0.001$ \\
\hline \multicolumn{7}{|l|}{ Effort } \\
\hline Hunts intensively (2-5 times per week) & 0.09 & 76.9 & 37.9 & 62.2 & 9.71 & 0.008 \\
\hline Hunts regularly (1-4 times per month) & 0.07 & 7.7 & 48.3 & 37.8 & 7.42 & 0.025 \\
\hline Hunts occasionally & 0.07 & 15.4 & 13.8 & 0 & 6.97 & 0.031 \\
\hline \multicolumn{7}{|l|}{ Transport } \\
\hline On foot & 0.20 & 46.2 & 67.2 & 97.8 & 20.89 & $<0.001$ \\
\hline Bus or other public transport & 0.16 & 38.5 & 37.6 & 4.4 & 16.57 & $<0.001$ \\
\hline Motorbike-own & 0.12 & 30.8 & 5.3 & 2.2 & 13.34 & 0.001 \\
\hline Motorbike-rented & 0.05 & 7.7 & 12.1 & 0 & 5.76 & 0.56 \\
\hline
\end{tabular}




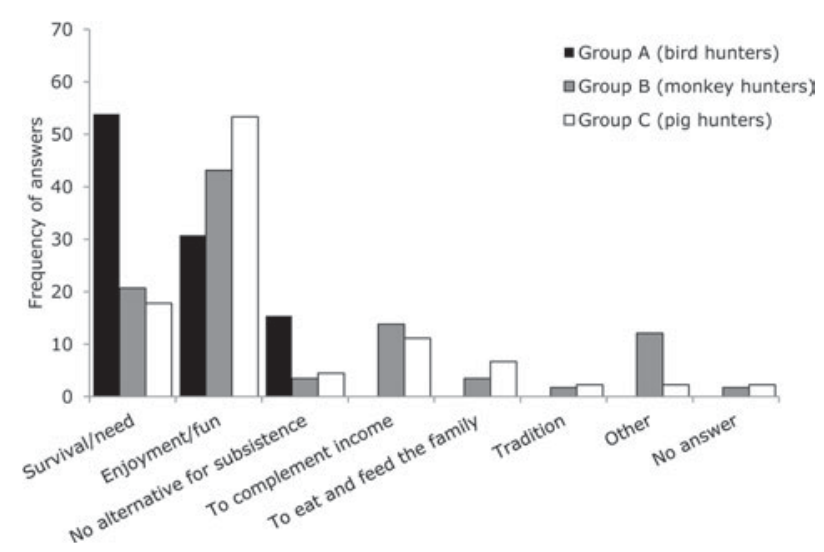

FIG. 2 Distribution of responses given by the hunters of São Tomé Island in relation to their reasons for hunting.

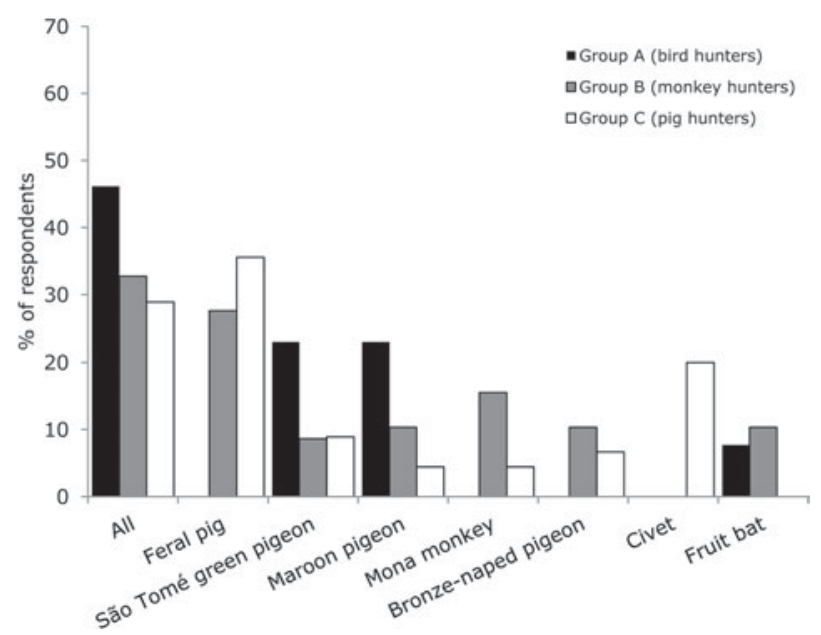

FIG. 3 Distribution of responses given by the hunters of São Tomé Island in relation to perceived changes in populations of prey species during the previous decade.

time spent hunting birds is much shorter compared to hunting of other wildlife. Bird hunting is also more lucrative than hunting pigs or monkeys because the return on investment is higher. The cost of air guns and pellets is lower than that of shotguns and cartridges and the price offered per bird is high per weight basis.

Although it is difficult to assess the numbers of birds traded domestically and locally because most do not pass through markets, there is likely to be a high demand for birds in city restaurants. According to our informants hunted birds are bought almost immediately and are often pre-ordered from hunters by restaurants and local traders. Although direct evidence of the effect of hunting on bird populations is not yet available, hunters claim that a decade earlier they shot hundreds of birds at a time, particularly pigeons, whereas now only dozens are taken. Historical accounts suggest that large numbers of pigeons were hunted in the 1950 and that these species were widely distributed (Snow, 1950; Amadon, 1953; de Naurois, 1983, 1988). Most hunters in our study acknowledged a negative trend in the abundance of all exploited species, especially pigeons, which most linked to a higher number of hunters. Although declines in introduced mammals were reported, endemic pigeons are probably the taxa most threatened by overhunting (Collar \& Stuart, 1988; Christy \& Clarke, 1998; Dallimer et al., 2009; Olmos \& Turshak, 2010; de Lima et al., 2013).

In contrast, the hunting of pigs and monkeys not only reduces the effect of these introduced mammals on the native species but also provides a reliable, culturally acceptable and free source of meat and income for a substantial number of families. Our study is a first step towards understanding the significance of hunting practices and their long-term effects on the biota and ecosystems on São Tomé. Elucidating the dynamics and long-term ecological effects of pigs and monkeys is a crucial step towards increasing our understanding of, and more effectively managing, biotic interactions on this island and thus preserving its valuable habitats and endemic species. Although our study is a useful step in characterizing the hunters, their motivations and target species, data on the actual and potential effects of hunting on prey populations are also essential.

Exploitation of wildlife is unhindered throughout São Tomé because there are few legal or other types of restrictions. As in most other west-central African countries hunting legislation on the island is poor and there is limited capacity for law enforcement (Bowen-Jones et al., 2002; Rowcliffe et al., 2004). Furthermore, hunters and game consumers on the island are unaware of the legislation and most do not know the difference between endemic, native and exotic species, or the conservation problems resulting from overhunting. Controlling bird hunting and regulating the trade to restaurants will require a combination of enforcement of legislation and raising awareness among stakeholder groups (including restaurants). Hunting regulations for endemic birds must be evidence-based. If hunting quotas for endemic pigeons, and perhaps other species, are to be implemented, knowledge of densities, association with the various habitat types and breeding seasonality is fundamental. Capturing the knowledge of hunters and developing a common base from which to regulate hunting needs to be done urgently. Farming of native species such as the São Tomé harlequin quail Coturnix delegorguei histrionica, which is already widely bred in aviaries, could fulfil the demand for birds in restaurants and could create incentives for bird hunters to shift to mammal hunting.

\section{Acknowledgements}

We thank all the São Tomé hunters and informants who collaborated in the study. For local support we thank the General Director for the Environment Eng. 
Arlindo Carvalho and Dr Vitor Bonfim and Eng. Salvador Pontes from the Directorship for Conservation. Technical support and advice were provided by the Associação Monte Pico, particularly Luis Mário Almeida and Gabriel. MC was supported by a Rufford Small Grant for Conservation of Nature and funded by the Portuguese Government (Foundation for Science and Technology-FCT/MCTES), project PTDC/BIA-BIC/115223/2009 and grant SFRH/BD/ $30171 / 2006$.

\section{References}

Albuquerque, C. \& Cesarini, D. (2009) Plano de Gestão do Parque Nacional Obô de São Tomé. ECOFAC IV, República Democrática de São Tomé e Príncipe.

Alkire, S., Roche, J.M., Santos, M.E. \& Seth, S. (2011) São Tomé and Príncipe Country Briefing. Oxford Poverty \& Human Development Initiative (OPHI) Multidimensional Poverty Index Country Briefing Series. Http://www.ophi.org.uk/wp-content/ uploads/Sao-Tome-and-Principe-OPHI-CountryBrief-2011.pdf. [accessed 28 November 2013].

Amadon, D. (1953) Avian systematics and evolution in the Gulf of Guinea. Bulletin of the American Museum of Natural History, 100, 394-451.

Atrinson, P.W., Peet, N.B. \& Alexander, J. (1991) The status and conservation of the endemic bird species of São Tomé and Príncipe, West Africa. Bird Conservation International, 1, 255-282.

Bennett, E.L., Blencowe, E., Brandon, K., Brown, D., Burn, R.W., Cowlishaw, G., et al. (2007) Hunting for consensus: reconciling bushmeat harvest, conservation, and development policy in West and Central Africa. Conservation Biology, 21, 884-887.

Bernard, R.H. (2006) Research Methods in Anthropology: Qualitative and Quantitative Approaches. Altamira Press, Lanham, USA.

Bibby, C.J., Collar, N.J., Crosby, M.J., Heath, M.F., Imbonden, C., Johnson, T.H. et al. (1992) Putting Biodiversity on the Map: Priority for Global Conservation. International Council for Bird Preservation, Cambridge, UK.

Birdife International (2012) Endemic Bird Area Factsheet: São Tomé. Http://www.birdlife.org/datazone/ebafactsheet.php? $\mathrm{id}=84$ [accessed 31 October 2012].

Bowen-Jones, E., Brown, D. \& Robinson, E. (2002) Assessment of the Solution-Orientated Research Needed to Promote a More Sustainable Bushmeat Trade in Central and West Africa. Report to the Wildlife and Countryside Directorate, DEFRA, London, UK.

Bowen-Jones, E., Brown, D. \& Robinson, E. (2003) Economic commodity or environmental crisis? An interdisciplinary approach to analyzing the bushmeat trade in central and west Africa. Area, 35, 390-402.

Buchanan, G.M., Donald, P.F. \& Butchart, S.H.M. (2011) Identifying priority areas for conservation: a global assessment for forest-dependent birds. PLOS ONE, 6, e29080.

Carvalho, S., De Oliveira, F. \& Vaz, H. (2004) Situation des Ressources Génétiques Forestières de la République Démocratique de São Tomé-et-Príncipe. Division des Ressources Forestières, FAO, Rome, Italy.

Christy, P. \& Clarke, W. (1998) Guide des Oiseaux de São Tomé et Príncipe. ECOFAC, São Tomé.

Cia (Central Intelligence Agency) (2012) The World Factbook. Https://www.cia.gov/library/publications/the-world-factbook/ index.html [accessed 31 October 2012].
Collar, N.J. \& STUart, S.N. (1988) Key Forests for Threatened Birds in Africa. ICBP Monograph 3. International Council for Bird Preservation, Cambridge, UK.

Covas, R. (2012) Evolution of reproductive life histories in island birds worldwide. Proceedings of the Royal Society, Series B, 279, 1531-1537.

Cruz, F., Donlan, C.J., Campbell, K. \& Carrion, V. (2005) Conservation action in the Galapagos: feral pig (Sus scrofa) eradication from Santiago Island. Biological Conservation, 121, 473-478.

Dallimer, M., King, T. \& Atkinson, R.J. (2009) Pervasive threats within a protected area: conserving the endemic birds of São Tomé, West Africa. Animal Conservation, 12, 209-219.

De Lima, R.F., Dallimer, M., Atkinson, P.W. \& Barlow, J. (2013) Biodiversity and land-use change: understanding the complex responses of an endemic-rich bird assemblage. Diversity and Distributions, 19, 411-422.

DE NAURoIs, R. (1983) Les oiseaux reproducteurs des iles de São Tomé et Príncipe: liste systématique commentée et indications zoogeographiques. Bonner Zoologische Beitrage, 34, 129-148.

De Naurois, R. (1988). Les Columbidae des iles de S. Tomé et Príncipe (1re partie). Cyanopica, 4, 217-242.

Desbiez, A.L.J., Keuroghlian, A., Piovezan, U. \& Bodmer, R.E. (2011) Invasive species and bushmeat hunting contributing to wildlife conservation: the case of feral pigs in a Neotropical wetland. Oryx, 45, 78-83.

Didham, R.K., Ewers, R.M. \& Gemmell, N.J. (2005a) Comment on 'Avian extinction and mammalian introductions on oceanic islands'. Science, 307, 1412.

Didham, R.K., Tylianakis, J.M., Hutchinson, M.A. \& Ewers, R. M. (2005b) Are invasive species the drivers of ecological change? Trends in Ecology and Evolution, 20, 470-474.

Duncan, R.P., Blackburn, T.M. \& Worthy, T.H. (2002) Prehistoric bird extinctions and human hunting. Proceedings of the Royal Society, Series B, 269, 517-521.

Dutton, J. (1994) Introduced mammals in São Tomé and Príncipe: possible threats to biodiversity. Biodiversity and Conservation, 3 , 927-938.

Fernandes-Ferreira, H., Mendonça, S.V., Albano, C., Ferreira, F.S. \& Alves, R.R.N. (2012) Hunting, use and conservation of birds in Northeast Brazil. Biodiversity and Conservation, 21, 221-244.

Furuichi, T. (2006) Red-tailed monkeys (Cercopithecus ascanius) hunt green pigeons (Treron calva) in the Kalinzu Forest in Uganda. Primates, 47, 174-176.

Glenn, M.E. \& Bensen, K.J. (1996) Surveys of mona monkeys on the island of São Tomé. Gulf of Guinea Conservation News, 6, 2-3.

Glenn, M.E. \& Cords, M. (2002) The Guenons: Diversity and Adaptation in African Monkeys. Kluwer Academic/Plenum Publishers, New York, USA.

Gurevitch, J. \& Padilla, D.K. (2004) Are invasive species a major cause of extinctions? Trends in Ecology and Evolution, 19, $470-474$.

Hodges, T. \& Newitt, M. (1988) São Tomé and Príncipe: From Plantation Colony to Microstate. Westview Press, Boulder, USA, and London, UK.

IBM (2011) IBM SPSS Statistics 20 Core System. SPSS Inc., Chicago, USA.

INESTP (Instituto Nacional de Estatística de São Tomé e Príncipe) (2012) São Tomé e Príncipe em Números. INESTP, São Tomé.

IUCN (2012) IUCN Red List of Threatened Species v. 2012.2. Http:// www.iucnredlist.org [accessed 31 October 2012]. 
Jones, P.J. (1994) Biodiversity in the Gulf of Guinea: an overview. Biodiversity and Conservation, 3, 772-784.

Jones, P.J. \& Tye, A. (1988) A Survey of the Avifauna of São Tomé and Príncipe. International Council for Bird Preservation, Cambridge, UK.

Jones, P.J. \& Tye, A. (2006) The Birds of Príncipe, São Tomé and Annobón-An Annotated Checklist. British Ornithologists' Union, Oxford, UK.

Ketchen, D.J. \& Shooк, C.L. (1996) The application of cluster analysis in strategic management research: an analysis and critique. Strategic Management Journal, 17, 441-458.

KirCH, P.V. (1997) Microcosmic histories: island perspectives on 'global' change. American Anthropologist, 99, 30-42.

Nogueira, S., Nogueira - Filho, S.L., B assford, M., Silvius, K. \& Fragoso, J.M.V. (2007) Feral pigs in Hawaii : using behaviour and ecology to refine control techniques. Applied Animal Behaviour Science, 108, 1-11.

Nogueira-filho, S.L.G., Nogueira, S.S.C. \& Fragoso, J.M.V. (2009) Ecological impacts of feral pigs in the Hawaiian Islands. Biodiversity and Conservation, 18, 3677-3683.

NowaK, R.M. (1991) Walker's Mammals of the World, Volume 1. 5th edition. The Johns Hopkins University Press, Baltimore, USA.

Oliveira, F.C.N. (2002). Monografia Sobre os Ecossistemas Florestais. Projecto de Elaboração da Estratégia Nacional e Plano de Ação da Biodiversidade, São Tomé e Príncipe.

Olmos, F. \& Turshak, L.G. (2010) Bird observations from São Tomé: Monte Carmo as a priority conservation site. Bulletin of the African Bird Club, 17, 54-65.

Pailler, S., Wagner, J.E., McPeak, J.G. \& Floyd, D.W. (2009) Identifying conservation opportunities among Malinké bushmeat hunters of Guinea, West Africa. Human Ecology, 37, 761-774.

Peet, N.B. \& Atrinson, P.W. (1994) The biodiversity and conservation of the birds of São Tomé and Príncipe. Biodiversity and Conservation, 3, 851-867.
Phillips, O., Gentry, A.H., Reynel, C., Wilkin, P. \& Galvez-Durand, B.C. (1994) Quantitative ethnobotany and Amazonian conservation. Conservation Biology, 8, 225-248.

Punj, G. \& Stewart, D.W. (1983) Cluster analysis in marketing research: review and suggestions for application. Journal of Marketing Research, 20, 134-148.

Rowcliffe, J.M., De Merode, E. \& Cowlishaw, G. (2004) Do wildlife laws work? Species protection and the application of a prey choice model to poaching decisions. Proceedings of the Royal Society B: Biological Sciences, 271, 2631-2636.

SnOw, D.W. (1950) The birds of São Tomé and Príncipe in the Gulf of Guinea. Ibis, 92, 579-595.

Stattersfield, A.J., Crosby, M.J., Long, A.J. \& Wege, D.C. (1998) Endemic Bird Areas of the World. Priorities for Biodiversity Conservation. BirdLife Conservation Series 7. BirdLife International, Cambridge, UK.

Steadman, D.W. (2006) Extinction and Biogeography of Tropical Pacific Birds. University of Chicago Press, Chicago, USA.

WALKER, J.S. (2007) Geographical patterns of threat among pigeons and doves (Columbidae). Oryx, 41, 289-299.

WARD, J. (1963) Hierarchical grouping to optimize an objective function. Journal of the American Statistical Association, 58, 236-244.

\section{Biographical sketches}

Mariana Carvalio's research is focused the ecology of Columbidae birds and the effect of hunting, with field work in Portugal, Guinea Bissau and São Tomé e Principe. Jo R G E P A L M E I R IM investigates the ecology of bats and birds, particularly in tropical areas. FRANCISCO REGO has considerable experience in forest research and management. Nelson Sole and Aristides Santana are involved in conservation work on São Tomé Island. J ULIA FA's research focuses on the interface between social and ecological systems in the context of the conservation of harvested species in Africa. 